\title{
Profitability and Credit Risk Management: A Comparative Study of Commercial Banks in Bangladesh.
}

\author{
Md. Nazmul Hasan*, Afrins Farid**, Chowdhury Abdullah Al Mamun*** \\ *Assistant Proferssor, Department of Business Studies, University of Information Technology and Sciences \\ **Assistant Professor, Department of Business Studies, University of Information Technology and Sciences \\ ***Lecturer, Department of Business Studies, University of Information Technology and Sciences
}

\begin{abstract}
This study examines Profitability and Credit Risk Management of Commercial Banks in Bangladesh. Information are collected from different news media, publication and some selected banks to describe present scenario of banking sector in Bangladesh. To analysis the profitability and credit risk management of banks after implementing the Basel II standard, we collect secondary data of five years (Y2007 to Y2011) from the Annual Report of the organizations. Horizontal and Vertical Analysis method are used to measure the profitability of the banks and interpret the Balance Sheet and Income Statement of the banks. Few bar-diagrams have been drawn to compare the performance among four banks. For this research, ROE, NPLR and CAR are calculated to evaluate the Credit Risk of the Banks. Using these three ratios, researchers construct the multiple regression models and use the F-test statistics.
\end{abstract}

\section{Introduction}

In the past two decades, the banking industry has evolved from a financial intermediation between depositors and borrowers, to a "one-stop" centre for a range of financial services like insurance, investments and mutual funds. The advancement of information and communicative technology (ICT) is given credit for the evolution of banking services, in particular, online banking. The development in ICT has not only provided vast banking opportunities previously beyond reach, but also heightens the competition and risks faced by banks in the financial system.

The objective of financial institutions is to maximize profit and shareholder value-added by providing different financial services mainly by managing risks. Bangladesh Bank, the prime supervisory authority of the financial sector implemented the new capital standard - Basel II from January 2009 in parallel with Basel I. From January 01, 2010 Basel II has been solely implemented in the banking sector. Basel II requires addressing and managing the market risk and operational risk in addition to the existing (as per Basel I) credit risk. Basel II capital standard is acting as a major catalyst for enrichment of risk management practices within the bank embedding the risk culture in the bank's operation. In response to the new capital accord (Basel II), risk management process within the bank has been introduced supporting the principles of more risk sensitive approach to capital adequacy.

Banks and similar financial institutions need to meet forthcoming regulatory requirements for risk measurement. However, it is a serious error to think that meeting regulatory requirements is the sole or even the most important reason for establishing a sound, scientific risk management system. Most of the parties involved in bank-dealings suffer from the following limitations: i) lack of proper identification of the determinants related to bankdealings; ii) failure to properly identifying risks involved in banking transaction; and iii) lack of knowledge to manage the risks faced by banks. All these necessities call for an in-depth investigation on risk management practices and lay the justification of this study.

\section{Objectives of the Study}

The ultimate aim of research is to how does credit risk management affect the profitability in commercial banks in Bangladesh. The specific objectives are given below:

* Comparing the financial performance of the banks.

* To measure the relationship between Credit Risk Management and Profitability of banks.

\section{Research Methodology}

According to the classification of research design my research project is "Exploratory Type". Exploratory research design management may have discovered general problems, but research is needed to gain better understanding of dimension of the problems. In the research project we try to find out the Comparative Study of the Profitability and Credit Risk Management in Banks in Bangladesh. In developing the data collection procedures, the researcher must establish and effective link between the information need and the questions to be asked or the observations to be recorded. The success of the study depends on researcher link 
and creativity in establishing this link. The responsibility for this task resets mainly with the researcher. Often quite the information needed to solve the problem can't be founding the firm own sales data or other interval records or published documents such as government, which are collected. The main motive of this research project is to measure the Profitability and Credit Risk Management of the banks of Bangladesh. However, it is not possible for time and cost to collect information from all the Banks. So the target population of my research project is commercial Bank. We have selected four major commercial banks in Bangladrsh: Bank Asia, Agrani Bank Limited, Prime Bank Limited and HSBC by using non-probability sampling methods. We collect data from the annual reports of 2007 to 2011 of each bank. Therefore, there are total 20 observations in the regression analysis. Here our selected four banks are different category. Here Bank Asia is Islamic bank, Agrani Bank Limited is government commercial bank, Prime Bank Limited is private commercial bank and HSBC is foreign and multinational commercial bank.

\section{Literature Review}

Risks are the uncertainties that can make the banks to loose and be bankrupt. According to the Basel Accords, risks the banks facing contain credit risk, market risk and operational risk. Credit risk is the risk of loss due to an obligator's non-payment of an obligation in terms of a loan or other lines of credit. The Basel committee proposes two methodologies for calculating the capital requirements for credit risk, one is to measure the credit risk in a standardized manner and the other is subject to the explicit approval of the bank's supervisor and allows banks to use the IRB approach. Market risk is defined as the risk of losses in on and off-balance sheet positions arising from movements in market prices. The capital treatment for market risk addresses the interest rate risk and equity risk pertaining to financial instruments, and the foreign exchange risk in the trading and banking books. The value at risk (VaR) approach is the most preferred to be used when the market risk is measured. Operational risk is defined as the risk of direct or indirect loss resulting from inadequate or failed internal processes, people and systems or from external events. There are three approaches applied to the operational risk measurement: Basic Indicator Approach (BIA), Standardized Approach (SA), and Advanced Measurement Approach (AMA).

Bank loan is a debt, which entails the redistribution of the financial assets between the lender and the borrower. The bank loan is commonly referred to the borrower who got an amount of money from the lender, and need to pay back, known as the principal. In addition, the banks normally charge a fee from the borrower, which is the interest on the debt. The risk associated with loans is credit risk. Credit risk is perhaps the most significant of all risks in terms of size of potential losses. Credit risk can be divided into three risks: default risk, exposure risk and recovery risk. As the extension of credit has always been at the core of banking operation, the focus of banks' risk management has been credit risk management. It applied both to the bank loan and investment portfolio. Credit risk management incorporates decision making process; before the credit decision is made, follow up of credit commitments including all monitoring and reporting process. The credit decision is based on the financial data and judgmental assessment of the market outlook, borrower, management and shareholders. The follow-up is carried out through periodic reporting reviews of the bank commitments by customer. Additionally, "warning systems" signal the deterioration of the condition of the borrower before default, whenever possible. Usually, loan becomes non-performing after being default for three months but this can depend on contract terms. NPLR shows the proportion of the default or near to default loans to the actual performing loans. It indicates the efficiency of the credit risk management employed in the bank. Therefore, the less the ratio the more effective the credit risk management. Usually, bank can project the average level of credit losses it can reasonably expect to experience. These losses are referred to:

A. Expected Losses (EL): perceived as cost of business undertaking by financial institutions;

B.Unexpected Losses (UL): losses above expected level when banks anticipate their occurrence though the timing and severity cannot be known beforehand. A few portions of unexpected losses might be absorbed by the interest rate charged on credit exposure although market will not support adequate prices to cover all unexpected losses.

C. Loss Given Default (LGD): the amount of fund that bank can lose when the borrower defaults on a loan. Therefore, capital is needed to cover the risks of such losses. Banks have an incentive to minimize capital they hold since reducing capital frees up economic resources that can be directed to profitable investment. In contrast, the less capital a bank holds, the greater is the likelihood that it will not be able to meet its own debt obligations, i.e. that losses in a given year will not be covered by profit plus available capital, and that the bank will become insolvent. Accordingly, banks must carefully balance the risks and rewards of holding capital. A number of approaches exist to determine how much capital a bank should hold. 
The IRB approach adopted by Basel II focuses on the frequency of bank insolvencies (the case of the bank failing to meet its senior obligations) arising from credit losses that supervisors are willing to accept. Through IRB approach, the Basel Committee intended to develop a framework which is credible, prudentially sound and reflect healthy risk management practices. Banks have made use of internal rating systems for very long time as a means of categorizing their exposure into broad, qualitatively differentiated layers of risk.

In our study, we try to examine the profitability of the banks. The profitability in our case is presented and measured using ROE. In other words, the amount of NI returned as a percentage of TSE. We choose it as profitability indicator because ROE comprises aspects of performance. The banks turn to focus on the ROE to measure the net profit to the book equity in order to find out the most profitable business and to do the investment. ROE is commonly used to measure the profitability of banks. The efficiency of the banks can be evaluated by applying ROE, since it shows that banks reinvest its earnings to generate future profit. The growth of ROE may also depend on the capitalization of the banks and operating profit margin. If a bank is highly capitalized through the risk-weighted capital adequacy ratio (RWCAR) or Tier 1 capital adequacy ratio (CAR), the expansion of ROE will be retarded. However, the increase of the operating margin can smoothly enhance the ROE. ROE also hinges on the capital management activities. If the banks use capital more efficiently, they will have a better financial leverage and consequently a higher ROE. Because a higher financial leverage multiplier indicates that banks can leverage on a smaller base of stakeholder's fund and produce higher interest bearing assets leading to the optimization of the earnings. On the contrary, a rise in ROE can also reflect increased risks because high risk might bring more profits. This means ROE does not only go up by increasing returns or profit but also grows by taking more debt which brings more risk. Thus, positive ROE does not only represent the financial strength. Risk management becomes more and more significant in order to ensure sustainable profits in banks.

\section{Financial Analysis of the Institutions}

Financial highlights of a company indicate summary of major financially related happenings within the company, often provided in a publicly-traded company's report to its shareholders. Highlights could include various performance statistics, net cash flow, or acquisition information. Government organizations often include financial highlights of individual department events.

\subsection{Comparative Study of the Total Shareholders' Equity}

To explain the Total Shareholders' Equity of four selected banks, a Bar-diagram is constructed as the data are in ordinal scale. Here the informations are proportion of Total Assets.

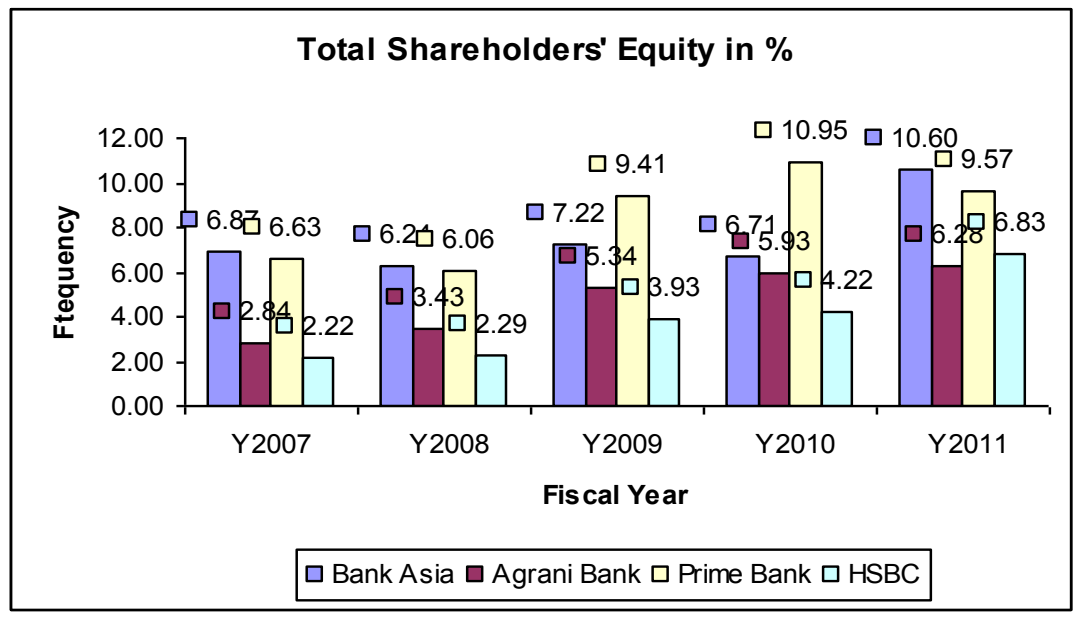

Figure 5.1: Total Shareholders' Equity of Four Banks

The above figure shows the precise frequencies for each category. Based on the bar-diagram in figure 5.1, it concludes that in Y2007 proportion of Bank Asia's total shareholder equity is the highest and HSBC's total shareholder equity is the lowest, which is $6.87 \%$ and $2.22 \%$ respectively. If we see the Y2008, Bank Asia is the first position, Prime Bank Limited is the second position, Agrani Bank is the third position and HSBC is the fourth position. To compare the Y2007, Y2008 and Y2009 total shareholder equity we see a positive trend of increasing the equity. In Y2011 the total shareholder equity only decrease Prime bank Limited (1.38\%) and the other three banks equity is increased the the previous year Y2010. So it is a positive thing that the all banks are try to overcome the global cricies of economy. 


\subsection{Comparative Study of the Total Profit after Tax}

To explain the Total Profit after Tax of the banks, the following Bar-diagram is constructed as the data are in ordinal scale. The informations are proportion of Interest Income.

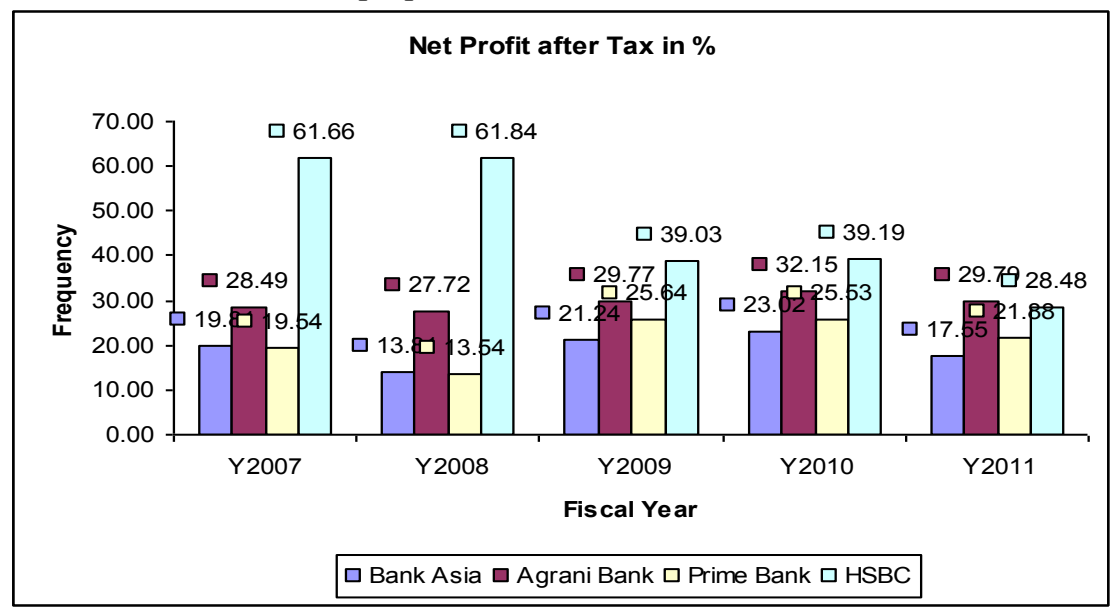

Figure 5.2: Net Profit after Tax of Four Banks

The figure shows the precise frequencies for each category. Here it shows that the proportion of Net Profit after Tax of four different banks (Bank Asia, Agrani Bank Limited, Prime Bank Limited and HSBC) and five different years performance (Y2007 to Y2011). According to the bar-diagram HSBC earned the highest amount of profit (61.66\%) and the second highest is Agrani Bank Limited. HSBC's Net Income follows a negative trend, which is very much bad thing for the bank's performance. Other three banks Net income trends follow an ups and downs trend. If we compare the last two years (Y2010 and Y2011) performance of those three banks we see that their performance decreased.

\subsection{Comparative Study of the Total Investments}

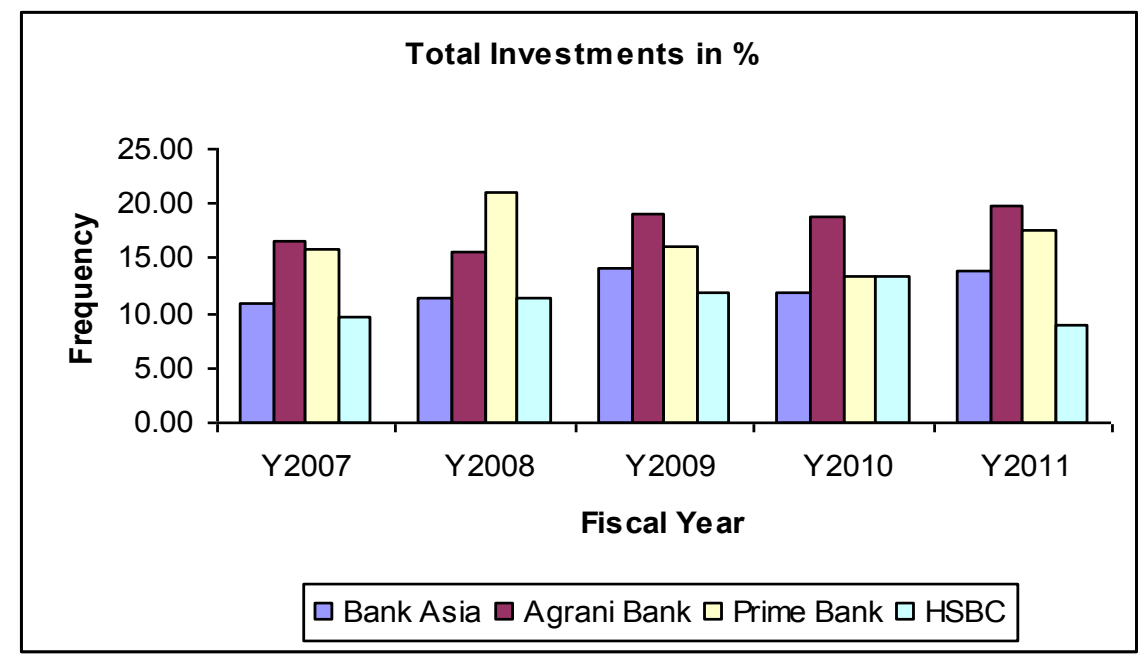

Figure 5.3: Total Investments of Four Banks

The figure shows the precise frequencies for each category. Here it shows that the proportion of Total Investment of four different banks and five different years performance (Y2007 to Y2011). Other we see all the four banks Total investment trends follow an ups and downs trend. According to the bar-diagram Prime Bank Limited earned the highest amount of Investment (20.92\%) in Y2008 and the second highest is Agrani Bank Limited (19.83\%) in Y2011. In Y2011 without HSBC's other three banks investment quantity increased compare to the previous year (Y2010). It is the positive side for the bank that tries to overcome the international sluggish economy. 


\subsection{Introduction}

\section{Credit Risk Management of the Institutions}

Credit risk management is a very important area for the banking sector and there are wide prospects of growth and other financial institutions also face problems which are financial in nature. Also, banking professionals have to maintain a balance between the risks and the returns. For a large customer base banks need to have a variety of loan products. If bank lowers the interest rates for the loans it offers, it will suffer. In terms of equity, a bank must have substantial amount of capital on its reserve, but not too much that it misses the investment revenue, and not too little that it leads itself to financial instability and to the risk of regulatory noncompliance. Credit risk management is risk assessment that comes in an investment. Risk often comes in investing and in the allocation of capital.

Credit risk management must play its role then to help banks be in compliance with Basel II Accord and other regulatory bodies. For assessing the risk, banks should plan certain estimates, conduct monitoring, and perform reviews of the performance of the bank. They should also do Loan reviews and portfolio analysis in order to determine risk involved.

Banks must be active in managing the risks in various securities and derivatives. Still progress has to be made for analyzing the credits and determining the probability of defaults and risks of losses. So credit risk management becomes very important tool for the survival of banks.

\subsection{Relationship between Credit Risk Management and Profitability in Four Banks}

Here it shows present regression results for the profitability part, where ROE is dependent variable. Table 6.1 shows that NPLR affects ROE positively. NPLR $\beta$ coefficient is 0.742 which means that one unit increase in NPLR increases ROE by 0.742 units while CAR is held constant. The statistical significance of NPLR on ROE is 0.0009 which is less than 0.05 . This means that NPLR predicts effect on ROE with $11.11 \%$ probability. CAR on the contrary has a negative $\beta$ coefficient -1.599 . This indicates that one unit increases in CAR will decrease ROE by 1.599 units, holding NPLR constant. The statistical significance of CAR is 0.0288 which is a sign of relatively low significance. It implies that CAR predicts ROE with $97.12 \%$ probability. Thus, the results of the analysis states that NPLR has positive on ROE; meanwhile CAR has negative and significant affect on ROE in comparison to NPLR.

Coefficient Summary Table of Four Banks

Model Summary Table of Four Banks

\begin{tabular}{|c|c|c|c|c|c|c|c|}
\hline ROE & $\beta$ Coef. & $\begin{array}{l}* * \text { Signif. } \\
\text { (P-value) }\end{array}$ & N. & $R^{2}$ & $R^{2}{ }^{\text {Adj. }}$ & $\mathbf{F}$ & $\begin{array}{c}\text { Model Signif. } \\
\text { (P-value) }\end{array}$ \\
\hline NPLR & 0.742 & 0.0009 & 20 & & & & \\
\hline CAR & -1.599 & 0.0288 & 20 & 0.714 & 0.6798 & 21.17 & 0.0004 \\
\hline
\end{tabular}

Furthermore, Table 6.2 presents the figures for the whole equation. $\boldsymbol{R}^{2}$ represents the prediction level of variance in ROE by NPLR and CAR, which is 0.714 . This means that $71.4 \%$ or ROE can be predicted from both NPLR and CAR. Between two independent variables NPRL more relatively predict ROE. This fact can be confirmed by the results of simple regression analysis conductd separately with each independent variable. The results show that NPLR has $61.74 \%$ predicting ability of ROE while CAR has only $44.17 \%$. Adjusted $\boldsymbol{R}^{2}$ (67.98\%) avoids the overestimation effect of adding CAR as second independent variable to the model. Therefore, adjusted $\boldsymbol{R}^{2}$ is treated as more accurate value even though $\boldsymbol{R}^{2}$ is differing by $3.42 \%(71.40 \%$ $67.98 \%=3.42 \%$ ).

According to the table of F-distribution, the critical value of $\mathrm{F}$ distribution at the 5\% significant level is 3.59. In Table 6.2, the statistic value of $F$ is 21.17 , which exceeds the critical value of $F$ (3.59). Hence, the regression as whole is significant; this means that NPRL and CAR relatively predict ROE. Furthermore, the Pvalue (significance) is 0.0004 , which also indicates that ROE is predicted with $99.96 \%$ probability by NPLR and CAR together and shows a statistically significant relationship among them. Therefore, the F-value, associate with P-value proves that there is a significant relationship between the profitability measured as ROE and credit risk management measured as NPLR and CAR.

To conclude the analysis of the relationship between profitability and credit risk management in the four commercial banks in Bangladesh, CAR contributed negatively to banks profitability, while NPLR showed positive effects. However, comparing these two factors, NPLR and CAR has significant effect on ROE. Overall, the results of our regression analysis show that credit risk management impact profitability on fairly significant 
level in four commercial banks. In order to get more comprehensive results and answer our research question, we examine how credit risk management effect profitability in each bank separately in the following sections.

\subsection{Relationship between Credit Risk Management and Profitability in Bank Asia}

Bank Asia defines its credit risk as the risk of loss if counterparties fail to fulfill their agreed obligations and that the pledged collateral does not cover the claims. The bank discloses that $90 \%$ of its RWAs is exposed to credit risk; therefore it is characterized as the largest risk. Each customer area and product area primarily bears the responsibility for managing credit risk in its operation. However, credit risk management framework (policies, instructions and guidelines) is consolidated and monitored by Group Credit and Risk Control Committee. The credit risk measurement is based on three parameters PD (Probability of Default), LGD (Loss Given Default), CCF (Credit Conversion Factors) with standardized and FIRB (Foundation Internal Rating Based) approaches.

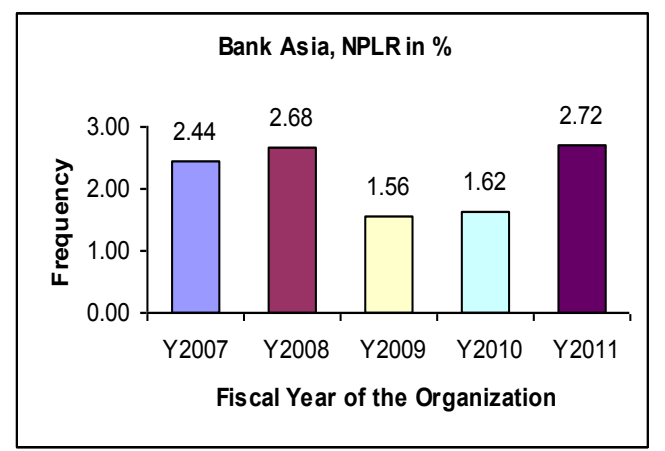

NPLR of Bank Asia 2007-2011, in \%

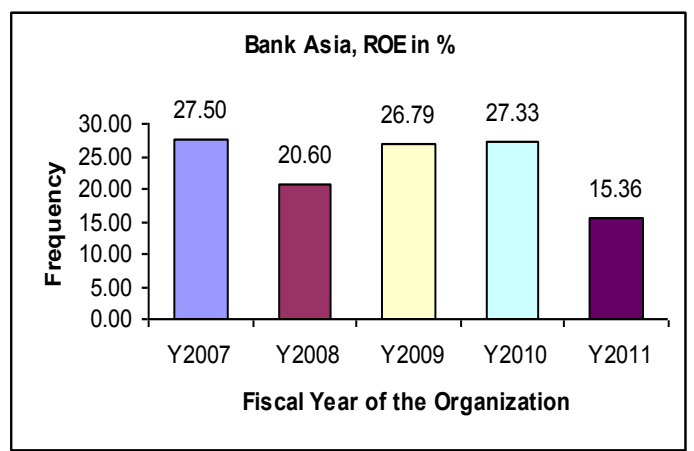

ROE of Bank Asia 2007-2011, in \%

The credit risk is assessed continuously by units in charge on customer level and if the any customer deviates from the agreed conditions the measures are taken to minimize the probable credit losses. In case the customer is unable to repay its debt obligations for 90 days the credit obligation becomes non-performing and if the situation can't be improved afterwards the credit obligation becomes default.

The Figure 6.1 shows that NPLR has visible decline since 2009 till 2010. However, in 2011 the ratio has increased $(0.162 \%$ to $0.272 \%)$ by $110 \%$. In comparison to other banks studied, Bank Asia's NPLR in year 2011 is lower than Agrani Bank Limited and HSBC Bank and higher than Prime Bank Limited. Without Agrani, other three banks have relatively higher NPLR in 2011 compared to previous years. We assume that this is caused by unstable financial market situation. Bank Asia has the lowest Total Loans and Advances amount among the studied banks. Lower NPLR in relation to highest TL amount can be explained by its credit risk management strategy described above. Also because of its ownership characteristics, Bank Asia's has sharp rise as in FY2011.

Figure 6.2 shows that during the period from 2007 to 2011 Bank Asia had the lowest ROE in 2011 and comparing with the other banks as well. This was due to the economic downturn, and the uncertainties on the equity market. The fall of equity- related revenues and interest rate, along with their influence on the deposit margin had a significant effect on the core income of Bank Asia. Bank Asia put a lot of efforts to improve performance through the strategies of ensuring the capital efficiency and maintaining the credit portfolio quality. These in consequence led to the continuous increase in ROE till 2010. But for the advent of the global financial crisis, the ROE decreased from $27.33 \%$ (2010) to $15.36 \%$ (2011).

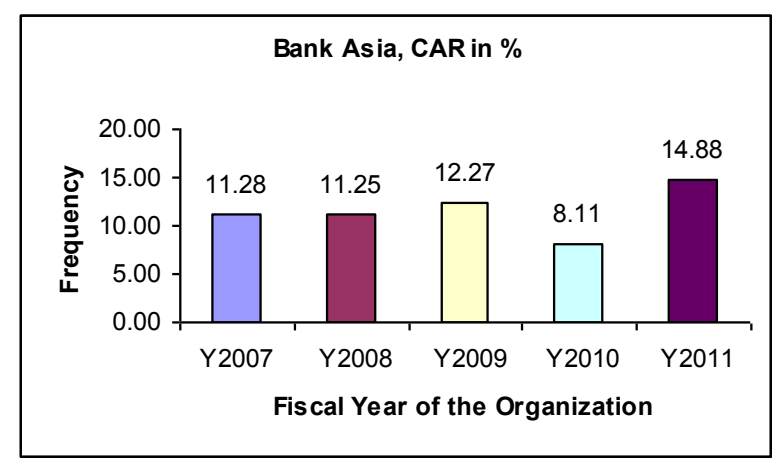

CAR of Bank Asia 2007-2011, in \% 
In order to keep strong capital position and to cover slightly increased RWA, Bank Asia's recent capital policy has been structured to have lower dividend payment along with active management of risk profile. The policy has an impact on the CAR level shown in Figure 6.3 as the highest in 2011. Nordea has a very strong capital position with total capital ratio of $14.88 \%$ in 2011 .

Table 6.3 Coefficient Summary Table of Bank Asia

\begin{tabular}{|c|c|c|c|c|c|c|c|}
\hline ROE & 及 Coef. & $\begin{array}{l}* * \text { Signif. } \\
\text { (P-value) }\end{array}$ & N. & $R^{2}$ & Adj. $R^{2}$ & $\mathbf{F}$ & $\begin{array}{c}\text { Model Signif. } \\
\text { (P-value) }\end{array}$ \\
\hline NPLR & -4.46 & 0.424 & 5 & & & & \\
\hline CAR & -1.04 & 0.428 & 5 & 0.686 & 0.372 & 2.18 & 0.0524 \\
\hline
\end{tabular}

The above Tables 6.3 and 6.4 present the regression analysis results of the profitability equation of Bank Asia. The coefficient (-4.46) shows that the NPLR has a weak negative effect on ROE in Bank Asia, which means that one unit increase of NPLR, ROE will decrease 4.46 units when CAR is held constant. The significance of NPLR is 0.424 , which is greater than 0,05 . This refers that the NPLR can predict ROE with $57.6 \%$ probability. CAR also shows a negative effect on ROE in Bank Asia with a $\beta$ coefficient of -1.04 . This indicates that one units increase in CAR will reduce ROE by 1.04 units, while the NPLR is held constant. The statistical significance of CAR is 0.428 . It implies that CAR can predict ROE with $57.2 \%$ probability.

In Table $6.4, \boldsymbol{R}^{2}(0.686)$ indicates the level of the prediction of NPLR and CAR on ROE; it means that $68.6 \%$ of ROE can be predicted by NPLR and CAR. It shows a high significant relationship between the profitability and credit risk management in Bank Asia. Furthermore, Adjusted $\boldsymbol{R}^{\mathbf{2}}(37.2 \%)$ and is considered as more reliable value for the model analysis.

According to the F-distribution table, the critical value of $\mathrm{F}$ distribution at 5\% significant level is 19.00 , in Table 6.4 the statistic value of $\mathrm{F}$ is 2.18 , which is less than Therefore, the regression of the equation for Bank Asia is insignificant; this means that NPLR and CAR can't reliably predict ROE in Bank Asia. In addition, the P-value in Table 6.4 is 0.0524 , this reflect that the NPLR and CAR together predict $94.76 \%$ of ROE. Thus the Fvalue associate with the P-value from the regression outputs show that there is significant relationship between the profitability and credit risk management in Bank Asia.

To sum up the analysis above, both NPLR and CAR have the negative effects on ROE, it refers that the credit risk management contribute a negative effect on the profitability in Bank Asia.

\subsection{Relationship between Credit Risk Management and Profitability in Agrani Bank Limited}

Risk management in Agrani Bank is a prior working area, and it is continuously developed. The profitability of Agrani Bank depends on the capability to access, manage and price the risks that it is facing. Furthermore in order to meet the unforeseen problems, Agrani Bank puts a lot of efforts to maintain a sufficient capitalization. Therefore, Agrani Bank's risk policy is to identify, manage and monitor the risks and capital related issues in an early stage to ensure the financial stability. Credit risk in Agrani Bank refers to the risk of loss due to the failure of an obligor to fulfill its obligations towards Agrani Bank.

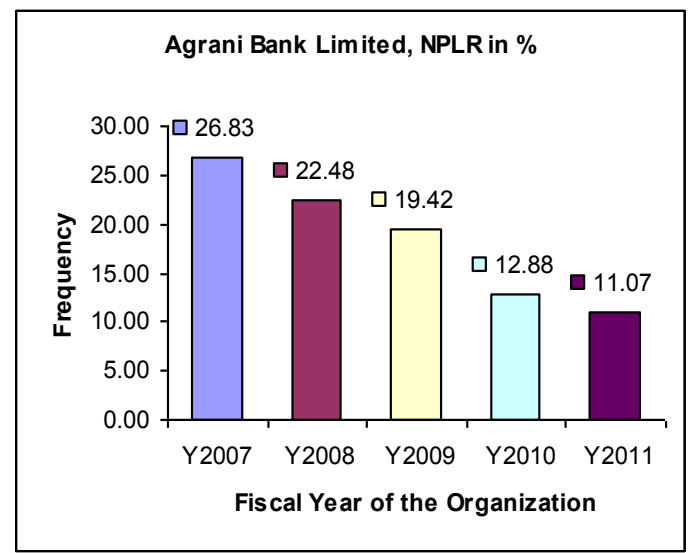

Fig 6.4: NPLR of Agrani Bank 2007-2011, in \%

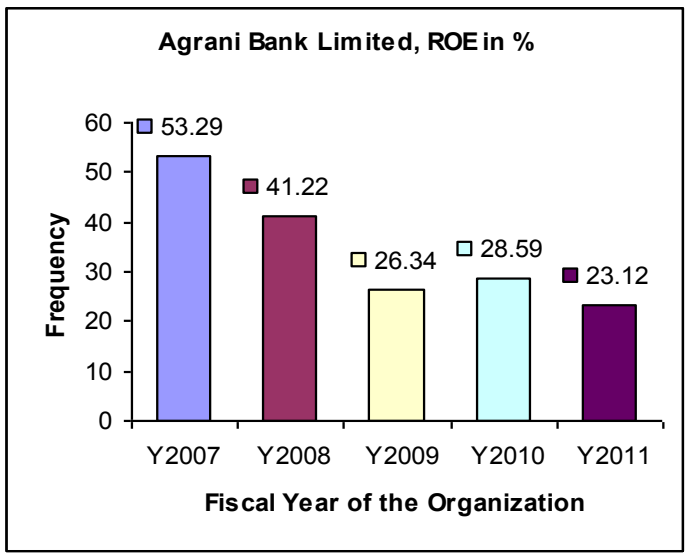

Fig 6.5: ROE of Agrani Bank 2007-2011, in \% 
According to the graphical analysis we can illustrates the NPLR of the Agrani Bank is the bightest from other three banks. Since 2007 to 2011, Agrani Bank's NPLR decreased dramatically comparing with the previous years (Figure 6.4). The reasons, we assume, are the downturn economic situation and the worldwide financial crisis which to some extent led to high NPLR in 2011.

Figure 6.5 shows decrease in ROE till the year 2009. However, ROE started to increase in 2010 (28.59\%) and it again decrease $5.47 \%(28.59 \%-23.12 \%=5.47 \%)$ till 2011 . This is because of the unprecedented financial turbulence, which brought higher risk and reduced the trust of the financial institutions, consequently had the negative effects on the profitability.

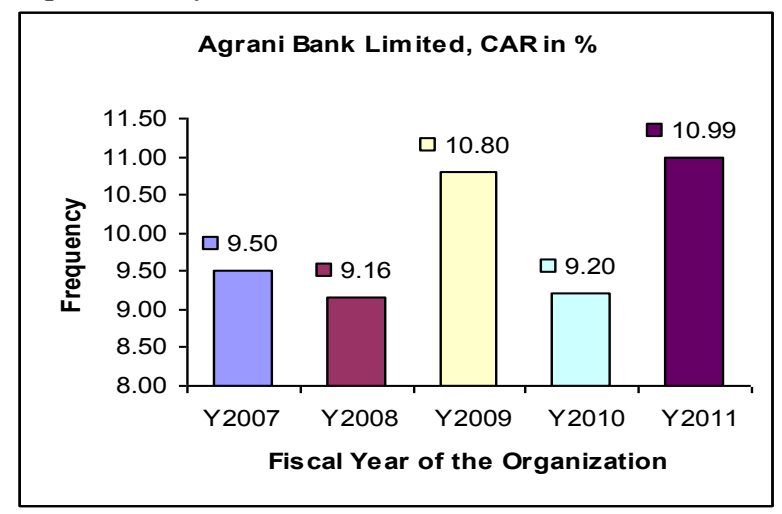

Figure 6.6: CAR of Agrani Bank 2007-2011, in \%

Figure 6.6 shows that CAR was highest in 2011, 10.99\%. In 2007 and 2008 CAR is continuously decreased. But in 2009 CAR is dramatecially increased $10.64 \%$ from the previous year 2008 and the next year it sharply decrease $10.60 \%$ in 2010 . this is very much negative side for the organization and it badly effect the profitability of the bank.

Table 6.5 Coefficient Summary Table of Agrani Bank Limited
Table 6.6 Model Summary Table of Agrani Bank Limited

\begin{tabular}{|c|c|c|c|c|c|c|c|}
\hline ROE & $\beta$ Coef. & $\begin{array}{l}* * \text { Signif. } \\
\text { (P-value) }\end{array}$ & N. & $R^{2}$ & $\operatorname{Adj} \cdot R^{2}$ & $\mathbf{F}$ & $\begin{array}{c}\text { Model Signif. } \\
\text { (P-value) }\end{array}$ \\
\hline NPLR & 1.451 & 0.109 & 5 & & & & \\
\hline CAR & -4.433 & 0.368 & 5 & 0.875 & 0.75 & 7.00 & 0.354 \\
\hline
\end{tabular}

Table 6.5 shows that NPLR has a positive effect on ROE with a $\beta$ coefficient 1.451 . This means that one unit increases in NPLR; ROE will increase by 1.451 units, while CAR is held constant. The statistical significance of NPLR is 0.109 ; this tells that $89.1 \%$ of the variance of ROE can be predicted by NPLR. However, CAR has a visible negative effect on ROE. It refers if CAR increases one unit, ROE will decrease 4.433 units, when NPLR is held constant. Comparing with NPLR, CAR has the significance 0.368, which indicates that the regression is insignificant, since it is higher than 0.05 . CAR has a reliable prediction probability $(63.2 \%)$ on ROE.

From the table $6.6 \boldsymbol{R}^{2}(0.875)$ represents the prediction level of ROE by NPLR and CAR together. It means that $87.53 \%$ of change in ROE can be predicted by NPLR and CAR, which shows that the credit risk management in Agrani Bank has a significant effect on its profitability. In addition, the Adjusted $\boldsymbol{R}^{2}(75.0 \%)$ is considered a more reliable value for the regression analysis.

According to the F-distribution table, the critical value of $\mathrm{F}$ distribution at $5 \%$ significant level is 19.00 while in Table 6.6 the statistic F-value is 7.00 , which is smaller than the critical F-value. Therefore, the regression of the equation for Agrani Bank is insignificant; this means that NPLR and CAR can't reliably predict ROE in Agrani Bank. In addition, the P-value is 0.354; this reflects that the NPLR and CAR together predict $64.6 \%$ of the differences in ROE correctly. Thus, F-value and associated P-value show that there is insignificant relationship between the profitability and credit risk management in Agrani Bank.

To sum up the analysis above, the credit risk management has a substantial effect on the profitability in Agrani Bank. According the regression outputs, NPLR has higher prediction ability than CAR. 


\subsection{Relationship between Credit Risk Management and Profitability in Prime Bank Limited}

Prime Bank Limited defines credit risk as "the risk of the Bank facing economic loss as the result of the Bank's counterparties not being able to fulfill their contractual obligations". Bank follows its traditional low risk tolerance conception over the years and stays loyal to it. The Bank does not disregard its quality requirements for credit lending to achieve high loan volumes or higher returns. The local involvement is another characteristic of the Bank's credit risk management. Branches keep ongoing customer relationship with their clients. It gives them opportunity to have in-depth understanding of each individual customer's current situation. Therefore, they can prevent significant credit losses since they become aware about the arising problem at the early stages. The Bank keeps its credit risks (loans and similar products) on the book rather than securitizing and selling them. By doing that Bank strengthens client's loyalty and trust.

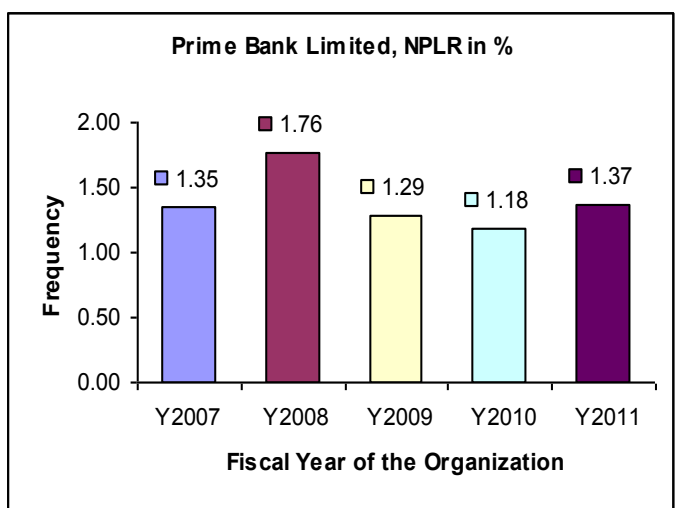

Fig 6.7: NPLR of Prime Bank 2007-2011, in \%

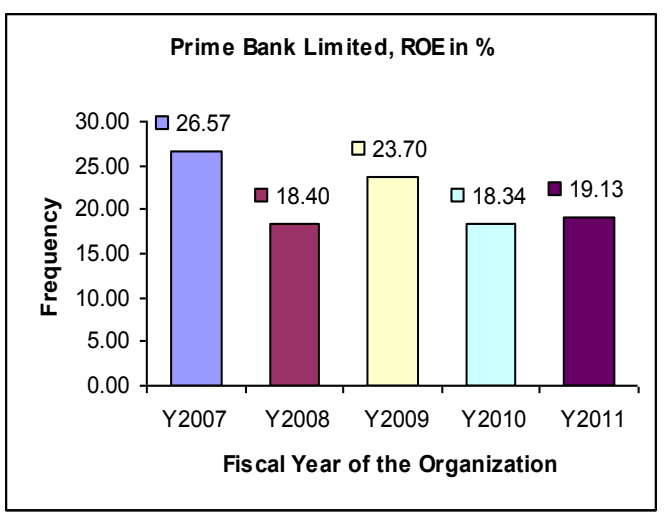

Fig 6.8: ROE of Prime Bank 2007-2011, in \%

According to the graphical analysis we can illustrates the NPLR of the Prime Bank Limited is the lowest from other three banks. Since 2008 to 2010, Prime Bank Limited's NPLR decreased slowly and in 2011 it increase $19.0 \%$ than the previous year.

Figure 6.8 shows that during the period from 2007 to 2011 Prime Bank Limited had high ROE compare to the other three banks. In 2007 the bank has the highest ROE (26.57\%) after then it decrease in 2008 (18.40\%). In 2009 the ROE is the second highest and the next two years ROE decrease slowly $4.57 \%$ till 2011.

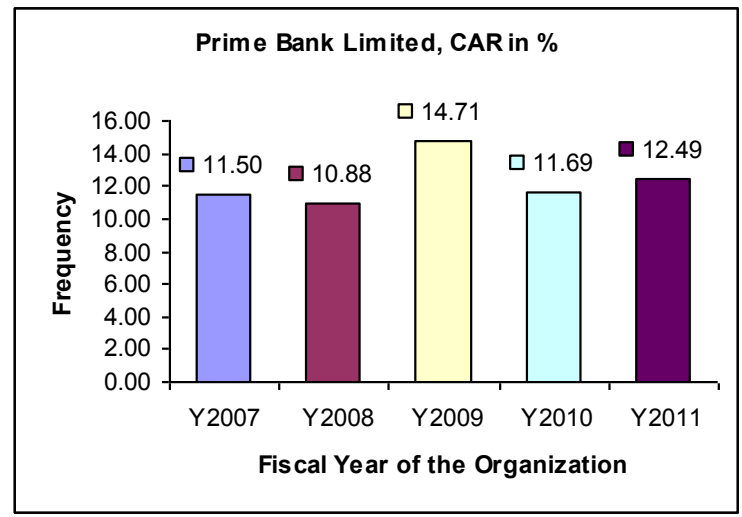

Figure 6.9: CAR of Prime Bank 2007-2011, in \%

Figure 6.9 shows that CAR was highest in 2009, 14.71\%. In 2007 and 2008 CAR is continuously decreased. But in 2009 CAR is increased 3.02\% from the previous year 2008 and the next year it slowly decrease and reach $10.88 \%$ in 2010 . This is very much negative side for the organization and it badly affects the profitability of the bank.

Here Table 6.7 and 6.8 present regression results for the profitability part, where ROE is dependent variable. Table 6.7 shows that NPLR affects ROE negatively. NPLR $\beta$ coefficient is -2.454 which means that one unit increases in NPLR and decreases ROE by 2.454 units while CAR is held constant. The statistical significance of NPLR on ROE is 0.865 which is greater than 0.05 . This means that NPLR predicts effect on ROE with $13.5 \%$ probability. CAR on the contrary has a positive $\beta$ coefficient 0.633 . This indicates that one 
unit increases in CAR will increase ROE by 0.633 units, holding NPLR constant. The statistical significance of CAR is 0.768 which is a sign of relatively low significance. It implies that CAR predicts ROE with $23.2 \%$ probability. Thus, the results of the analysis states that NPLR has negative on ROE, meanwhile CAR has positive and significant affect on ROE in comparison to NPLR.

Table 6.7 Coefficient Summary Table of Prime Bank Limited

\begin{tabular}{|c|c|c|c|c|c|c|c|}
\hline ROE & $\beta$ Coef. & $\begin{array}{l}* * \text { Signif. } \\
\text { (P-value) }\end{array}$ & N. & $R^{2}$ & $\begin{array}{l}\text { Adj. } \\
R^{2}\end{array}$ & F & $\begin{array}{c}\text { Model Signif. } \\
\text { (P-value) }\end{array}$ \\
\hline NPLR & -2.454 & 0.865 & 5 & & & & \\
\hline CAR & 0.633 & 0.768 & 5 & 0.119 & -0.761 & 0.14 & 0.88 \\
\hline
\end{tabular}

Furthermore, Table 6.8 presents the figures for the whole equation. $\boldsymbol{R}^{2}$ represents the prediction level of variance in ROE by NPLR and CAR, which is 0.119 . This means that $11.9 \%$ of ROE can be predicted from both NPLR and CAR. Adjusted $\boldsymbol{R}^{2}$ is negatively associated.

According to the table of F-distribution, the critical value of $\mathrm{F}$ distribution at the $5 \%$ significant level is 19.00. In Table 6.8, the statistic value of $F$ is 0.14 , which is less then the critical value of $F(19.00)$. Hence, the regression as whole is insignificant; this means that NPRL and CAR relatively can't predict ROE. Furthermore, the P-value (significance) is 0.88 , which also indicates that ROE is predicted with $12.0 \%$ probability by NPLR and CAR together and shows a statistically insignificant relationship among them. Therefore, the F-value, associate with P-value proves that there is an insignificant relationship between the profitability measured as ROE and credit risk management measured as NPLR and CAR.

\subsection{Relationship between Credit Risk Management and Profitability in HSBC}

Nonetheless, Loans are classified as impaired loans (NPLs) if payments are unlikely to be made in accordance with contract items. Looking at the Figure 6.10, we can see that NPLR has shown a slowly decreasing trend from the year 2007 till 2009. The dramatic event in global financial market left a mark by contributing to a sharp increase in NPLR from 2009 to 2010 (2.92\% to $4.09 \%)$.

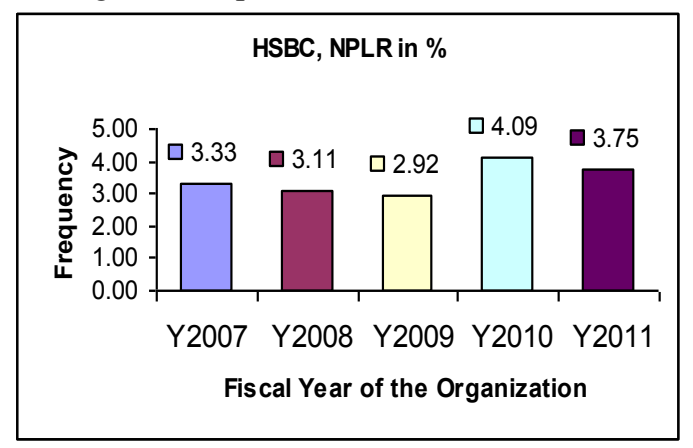

Fig 6.10: NPLR of HSBC 2007-2011, in \%

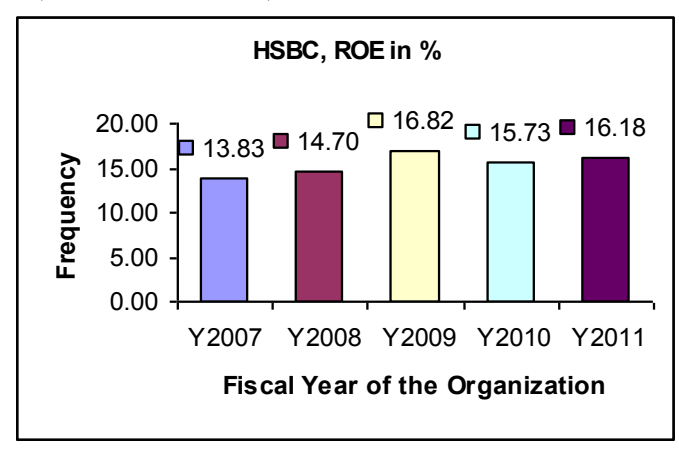

Fig 6.11: ROE of HSBC 2007-2011, in \%

Figure 6.11 since 2007 to 2009 the ROE slowly increase and in 2009 the ROE is the highest (16.82\%). After 2009 the ROE is slowly decrease till 2011 (16.18\%).

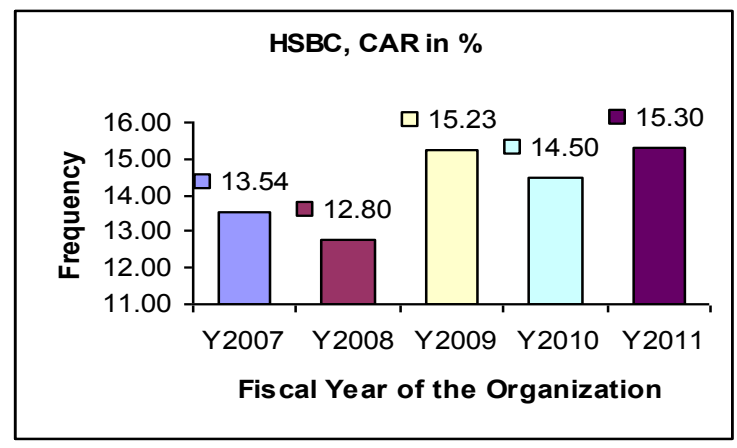

Fig 6.12: CAR of HSBC 2007-2011, in \% 
Figure 6.12 shows that CAR was highest in 2011, $15.30 \%$. There are ups and downs in the CAR of HSBC bank during the period from 2007 to 2011 . In 2008 CAR is the lowest value $12.80 \%$. This is very much negative side for the organization and it badly affects the profitability of the bank.

Table 6.9 Coefficient Summary Table of HSBC

Table 6.10 Model Summary Table of HSBC

\begin{tabular}{|c|c|c|c|c|c|c|c|}
\hline ROE & 及 Coef. & $\begin{array}{l}* * \text { Signif. } \\
\text { (P-value) }\end{array}$ & N. & $R^{2}$ & Adj. $R^{2}$ & $\mathbf{F}$ & $\begin{array}{c}\text { Model Signif. } \\
\text { (P-value) }\end{array}$ \\
\hline NPLR & -0.445 & 0.671 & 5 & & & & \\
\hline CAR & 0.984 & 0.131 & 5 & 0.756 & 0.513 & 3.11 & 0.659 \\
\hline
\end{tabular}

Table 6.9 above shows that NPLR $\beta$ coefficient is -0.445 which means that one unit increase in NPLR decreases ROE by 0.445 units, when CAR held constant. The statistical significance of NPLR is 0.671 which is way above than 0.05 . This means that NPLR predicts the variances in ROE with $32.9 \%$ probability. On the Otherhand CAR has a positive $\beta$ coefficient of 0.984 . It can be explained as one unit of increase in CAR will increase the ROE by 0.984 units. And the significance level in this case is 0.131 which is also way beyond 0.05 . This means that CAR can predict the changes in ROE with $86.9 \%$ probability. Therefore, we can state that NPLR has negative and CAR has positive effect on ROE while in this specific case CAR more relaibly predicts ROE than NPLR.

Table 6.10 shows the value of $\boldsymbol{R}^{2}$ is 0.756 which pointed toward the predicting ability of NPLR and CAR on the differences in ROE is at $75.6 \%$. Statistically such a low value for $\boldsymbol{R}^{2}$ indicates the relationship of ROE and NPLR, and CAR is by chance. Moreover, the not large difference between $\boldsymbol{R}^{2}$ and adjusted $\boldsymbol{R}^{2}$ also confirms the possibility of by chance relationship. Specifically, adjusted $\boldsymbol{R}^{2}$ of 0.513 indicates $51.3 \%$ probability of true relation. The resulted F-value in case of HSBC is 3.11 whereas critcal F-value is 19.00 and is higher than the resulted value. Hence, the regression equation as a whole is insignificant. The associated P-value in the table is 0.659 which means that NPLR and CAR can't relatively predict ROE with about $34.1 \%$ probability. Thus we can say that the relationship of ROE, NPLR and CAR is ambiguous: neither true nor by chance when it comes to HSBC. To conclude, the effect of credit risk management on profitability seem not to be clear in HSBC. From above discussion, it can be said that CAR is likely to have an effect on ROE more than NPLR.

\section{Summary and Conclusion}

According to the analysis above, the main findings of our study are summarized as follows:

Table 7.1 Summary of Regression Results

\begin{tabular}{|c|c|c|c|c|c|c|c|}
\hline & $\begin{array}{c}\text { All Four } \\
\text { Banks }\end{array}$ & Bank Asia & $\begin{array}{c}\text { Agrani Bank } \\
\text { Limited }\end{array}$ & $\begin{array}{c}\text { Prime Bank } \\
\text { Limited }\end{array}$ & HSBC & $\begin{array}{c}\text { Before } \\
\text { Basel II }\end{array}$ & $\begin{array}{c}\text { After } \\
\text { Basel II }\end{array}$ \\
\hline $\begin{array}{c}\boldsymbol{\beta} \text { of } \\
\text { NPLR }\end{array}$ & 0.742 & -4.46 & 1.451 & -2.454 & -0.445 & 0.6190 & 0.2940 \\
\hline $\begin{array}{c}\boldsymbol{\beta} \text { of } \\
\text { CAR }\end{array}$ & -1.599 & -1.04 & -4.433 & 0.633 & 0.984 & -0.7350 & -1.7040 \\
\hline Adj. $\boldsymbol{R}^{2}$ & 0.68 & 0.372 & 0.75 & -0.761 & 0.513 & 0.4464 & 0.939 \\
\hline $\begin{array}{c}\text { Model Signif. } \\
\text { P-value }\end{array}$ & 0.0004 & 0.0524 & 0.354 & 0.88 & 0.659 & 0.2219 & 0.000024 \\
\hline
\end{tabular}

The regression outputs of all four banks show that CAR has negative and significant effect on ROE compared to NPLR. It indicates that profitability is fairly affected by credit risk management in this banking group. Since banks have different characteristics and risk management policies, credit risk management affect profitability on different levels in each bank (Table 6.13). In Bank Asia, both NPLR and CAR show negative effect on ROE, while NPLR has relatively more negative effects on ROE ( $\beta$ coefficient is -4.46 ). Thus, the credit risk management has negative effects on its profitability. In Agrani Bank Limited, NPLR contributes in positive way, while CAR contributes in negative way toward ROE. Both of them have significant influence on ROE. Therefore, credit risk management affects profitability significantly in Agrani Bank Limited. In Prime Bank Limited, the regression outputs clearly show that NPLR and CAR are not the reliable predictors of ROE. However, we can't claim if there is an effect of credit risk management on profitability or not. Because in case of Prime Bank Limited, there are might be different predictors than the ones we have used in our case (NPLR and CAR). In HSBC, both NPLR have negative and CAR have positive effect on ROE while CAR affects ROE 
more than NPLR. All in all, the credit risk management of Bank Asia and Agrani Bank Limited has relatively not similar impact on their profitability. But Prime Bank Limited and HSBC has relatively not similar impact on their profitability.

The analysis shows that the effect of NPLR on ROE has become stronger after Basel II regulation has been applied. Nevertheless, CAR seems to have very low impact on ROE after Basel II application. It is worth mentioning that the effect of Basel II on CAR of the banking group has an opposite impact on ROE compared to Basel I. Prior to the adoption of Basel II, however, NPLR and CAR appear to be appropriate predictors of ROE because the Adjusted $\boldsymbol{R}^{2}$ shows positive value $(0.939)$ and the P-value $(0.000024)$ remarkably exceeds the significant level of 0.05 .

\section{Recommendations}

This research discusses about profitability and Credit risk management of commercial banks of Bangladesh. Here, it mainly highlights about the Basel II rules and regulation applying before and after period. In Bangladesh January 01, 2010 pertains Basel II standard criteria to become the commercial banks activity in a structural way and the also makes the banking sector profitable.

From the result and evidence of the study, following recommendations should be made for the government, Bankers, planners, customers and other concerned people to increase the profitability and credit risk management process.

Few recommendations are given below:

1) Profitability of a bank depends on the amount of deposit collection, Total Shareholders' Equity, Loans and Advances. So the bankers must be aware about the loans and advances as Non-performing loans have a great impact on profitability and credit risk management.

2) Basel II rules and regulations are new for our country. So many bankers and general people do not have clear concept about this strategy.

3) It has been observed that the banks profitability index has increased day by day after using the Basel II strategy. The banker must need to apply this properly to make much profit and overcome the losses.

4) To increase the Profitability of banks, bankers must be honest and sincere about their duty.

\section{References}

[1]. Anderson T.W, (1984), An Introduction to Multivariate Statistical Analysis, $2^{\text {nd }}$ ed, John Wiley and Sons, Canada.

[2]. Buyan K.C, Multivariate Analysis and its Application, New Central Book Agncy (P) Ltd, India.

[3]. Churchill, G. A., Marketing Research, Methodological Foundation, $6^{\text {th }}$ ed, The Dryden Press Orlando.

[4]. Cockran, W. G., (1984), Sampling Techniques, $3^{\text {rd }}$ ed. New Delhi, Wiley Eastern.

[5]. Cooper, D. R. Mand Schindler, P. S. (2003), Business Research Methods, $7^{\text {th }}$ ed. New York, McGraw-Hill.

[6]. Mason, R. D. and Lind, D. A. (2002), Statistical Techniques in Business and Economics, $11^{\text {th }}$ ed. Irwin.

[7]. S.C. Gupta and V.K. Kapoor, Fundamentals of Mathematical Statistics.

[8]. Gerhard. S (2002) Risk management and value creation in financial institutions Illustrated edition, Published by John Wiley and Sons pp. 239

[9]. Joel Bessis (1998) Risk Management in Banking. John Wiley\&Sons.

[10]. Joetta Colquitt (2007) Credit risk management: how to avoid lending disasters and maximize earnings 3rd edition pp.144

[11]. Barrow M. (2001) Statistics for economics, accounting and business studies. Harlow, Published by Financial Times Press pp. 248250

[12]. Waymond A Grier (2007) Credit analysis of financial institutions 2nd Edition, Published by Euromoney Books pp.197

[13]. Bryman, Allan., Bell, Emma. (2007) Business Research Methods. Second Edition, Oxford University Press.

[14]. Annual Reports of Bank Asia 2007-2011

[15]. Annual Report of Agrani Bank Limited 2007-2011

[16]. Annual Report of Prime Bank Limited 2007-2011

[17]. Annual Report of HSBC 2007-2011 